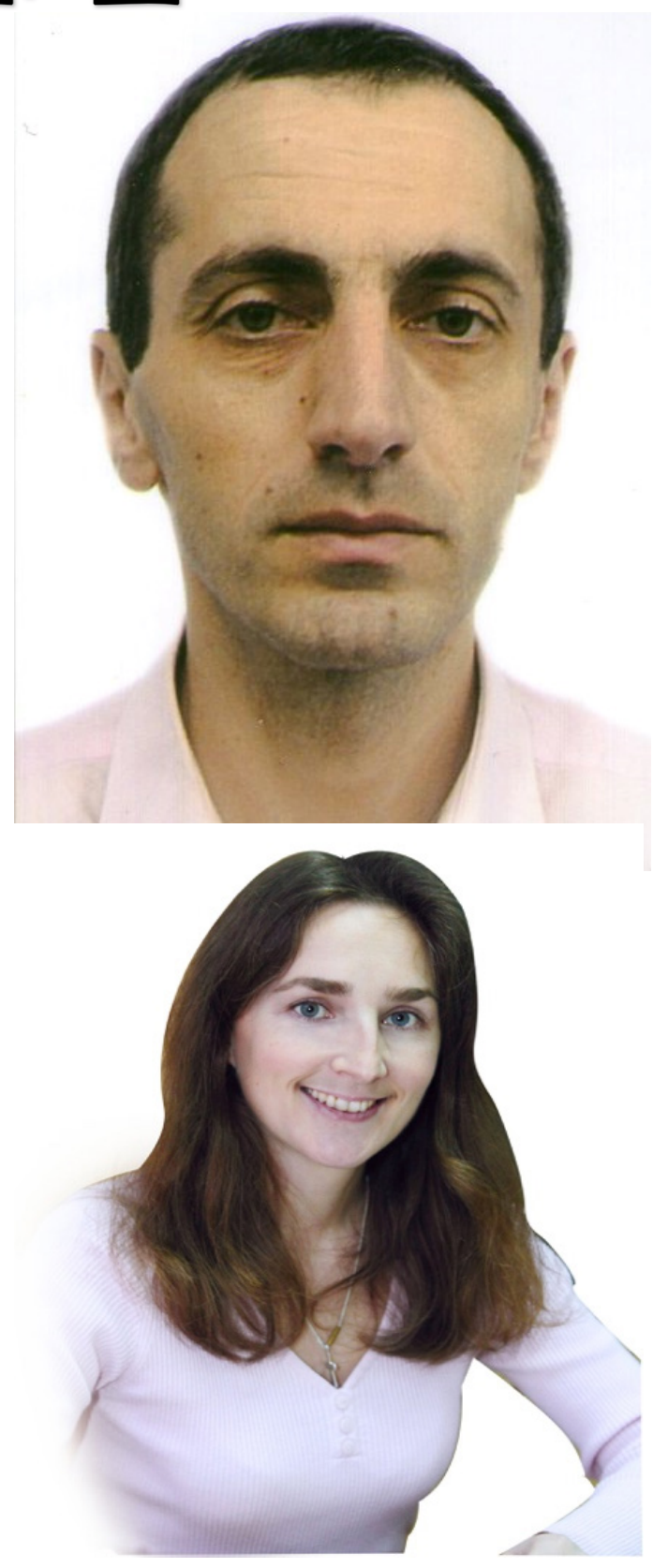

\author{
SELF IDENTIFICATION-OF THE \\ UKRAINIANS TROUGH PINING \\ FOR THEIR NATIVE LAND (ON THE \\ MATERIAL OF FOLK ART) \\ doi: 10.34142/astraea.2021.2.1.06
}

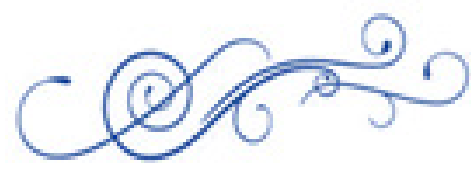

\section{TREHUBOV Dmytro}

Ph.D., Associate Professor, National University of Civil Protection of Ukraine, Kharkiv, cxxttregubov1970@nuczu.edu.ua, http://orcid.org/oooo-0003-1821-822X

\section{TREHUBOVA Iryna}

Head-methodologist, Public institution "Kharkiv Center for Children's and Youth Creativity No 1", Kharkiv, tregubova0606@gmail.com, https://orcid.org/oooo-0002-0787-8882

determined by the acute topicality of the studies concerning self-identification of the Ukrainians. Leaving the native land allows a person to better understand his/ her inner self. In the creative heritage of Ukraine, there are many mentionings of the types of separation from the native land and the reflection of personal attitude to it. Manifestations of this cultural phenomenon in different types of literary creativity are given close attention. The causes that add to the pining for the native land are classified, and their reflection in the literary heritage of the Ukrainian people is revealed. It is emphasized that for Ukraine, more often (C) Trehubov D., Trehubova I.,2021 


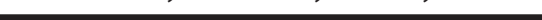

than for other states, this issue has repeatedly become relevant at different times. A new type of separation from the native land has been identified: the forced loss of the native language on one's own land. It is emphasized that some songs contain direct instructions to the listener on the principles of maintaining national identity. For example, the found version of the song "The falcon and eagle became friends" contains a new stanza with the request: "Teach my children / In a foreign land / not to seek for happiness". In the context of modern Ukrainian cultural background pining for the native land becomes topical, and the concept of "evshan-potion" is deemed really important. In general, this work shows that the cultural identity of Ukrainians has historical evidence, which is enshrined in folk songs and literary heritage. These results allow us to clarify the foundations of the cultural identity of the Ukrainians.

Keywords: folk art; self-identification; separation; Ukraine; Ukrainian; expansion of foreign cultures; loss of native language.

\section{АНОТАЦІЯ}

\section{Самоідентифікація українців на тлі туги за рідною землею (на матеріалі фольклору)}

Актуальність дослідження визначається загостренням проблеми самоідентифікації українців. Події останніх років, які загрожували втратою незалежності, стали для багатьох мешканців України поворотним моментом на шляху самоідентифікації та вибору відповідних змін у поведінці та способі мислення. Тобто, стан розлуки з рідною землею або загроза виникнення такого стану дозволяє людині краще зрозуміти власне ставлення до означеної проблеми. Тому в цій статті проведено аналіз пісенної творчості та виявлення у літературній спадщині України згадок про види розлуки з рідною землею та прояви особистісного ставлення до цієї проблеми.

У статті проаналізовано та систематизовано зразки української культурної спадщини на наявність елементів фіксації української ідентичності на тлі різних видів розлуки з батьківщиною. Розглянуто прояви даного культурного явища у різних видах літературної творчості. Здійснено класифікацію типів стану розлуки з рідною землею та виявлення їх відображення у пісенній та літературній спадщині українського народу. Акцентовано, що для України, як для ніякої іншої держави, це питання набувало актуальності багато разів у різні 
часи. Виділено новий тип відокремлення від рідного краю - вимушена втрата рідної мови на власній землі. Показано висвітлення цієї проблеми у народних та сучасних піснях. Зосереджено увагу на використанні типових знаків єдності з рідним краєм, які стали символами України. Наголошено, що деякі пісні містять прямі вказівки слухачеві щодо принципів підтримання національної ідентичності, так у знайденій версії пісні “Побратався сокіл...” є нова строфа, яка містить прохання: “Навчи ж моїх діток ... На чужині щастя ... не шукати”. У контексті сучасного стану культури та проблеми відокремлення від рідного краю розглядається парадигма поняття “євшан-зілля”. У цілому, ця робота показує, що культурна ідентичність українців має історичні докази, які закріплені у народній пісенності та літературній спадщині. Ці результати дозволяють з’ясувати основи культурної ідентичності багатьох народів на прикладі України.

Ключові слова: народна творчість; самоідентифікація; розлука; Україна; українець; експансія іноземних культур; втрата рідної мови.

\section{INTRODUCTION}

The topicality of the research is related to the question of self-identification of Ukrainians both from a historical perspective and in the present-time context. An important source of historical data on self-identification can be called cultural heritage.

In the process of analyzing the evidence of the most important manifestations of people's self-identification, it can be seen that these will not be historical records or documents of international agreements, but objects of cultural heritage and, above all, folk art. If we compare the folk art samples with the samples of fiction, we can see that the latter has an indirect reflection of the people's self-identification through the personal worldview of the author. Therefore, from our point of view, the emphasis in a study should be on the analysis of folk art.

Thus, it is important to find elements of Ukrainians' self-identification in folk art, namely those that help to reveal the attitude to the native land. As a person's feelings become stronger at a distance, the understanding of many life values comes to people in a state of separation from their homeland. This can be explained in terms of philosophy, which states that no system by internal means can detect its own contradiction. To identify such a problem, you need to look at it from the outside. 
Accordingly, a person outside his native land or in extreme conditions understands more acutely and accurately the relationship with the homeland. We have not found in the literary sources a systematic analysis of samples of folk, song, and literary works concerning the self-identification of the narrator in relation to Ukraine.

\section{LITERATURE REVIEW}

There are works series to identify the roots of the Ukrainian mentality as a philosophical, spiritual, and cultural manifestation of worldview and the formation in the self-consciousness of the corresponding image of the surrounding world. For example, one of the elements of such a worldview is the tendency of Ukrainians to "philosophy of the heart" (Bondarenko, 2008). Among the worldview of famous Ukrainian cultural figures, it is the philosophy of H.S. Skovoroda that belongs to this concept of understanding the world. This is not surprising, because by origin this thinker was the bearer of the Cossack Ukrainian mentality, which tended to the ideas of independence, honor, dignity, and the elevation of the spirit of freedom. Feeling death approaching during his spiritual travels, Skovoroda went to his native Ukraine, which best characterizes his Ukrainian self-identification. In this regard, we can mention two figures of Skovoroda's time, who also showed the Ukrainian mentality by their actions. First, it should be noted that Pavlo Konyushkevych taught poetics during Skovoroda's studying at the Kyiv-Mohyla Academy. Then he became the Metropolitan of Siberia, but, nevertheless, he continued speaking Ukrainian. Secondly, let us mention Georgy Konysky, who studied during Skovoroda's time and stayed at the academy to teach poetics, where he introduced a novelty: he added a section on the study of Ukrainian poetry to the curriculum (Tkachenko, 2014).

The work of O. Kuzmenko, in which the systematization of songs of folklore collections by F. Kolessa is carried out, is quite close to the consideration of the elements of reflection of separation from Ukraine, which is found in the texts of folk songs (Kuz $\square$ menko, 2013). This scientific work introduces a wide range of topics, which are under consideration in folk songs. But verbal representations of pining for the native land are not studied in this paper. In the above-mentioned work, there are useful elements of systematization for the chosen area of research, they are observed in the following key points: recruitment, request, funeral, death. For example, the song shows the sad parting of a recruit with relatives: "mother calls son to go home, because a letter came to go to war", "army recruit says goodbye to mother and his 
meant-to-be", "army recruit misses family", "an army recruit is worried because he is expecting a hated drill". There is a magical or other connection of the Cossack with relatives at the moment of death: "There is rye under the mountain, there the Cossack was killed" (three girls come to the Cossack, who show their longing for the one who died), "Oh, the fire is burning on the mountain" (mother, sister, wife fly to the Cossack in the form of three swallows), "Oh, fields, you, fields..." (the wounded Cossack sends home a horse as a messenger). Also, the author of this article draws attention to the words of the song "They are hewing sycamore": "The Cossack died, his language died...". Pidhorna (2013) investigated the national identity of Ukrainians on the basis of an analysis of folk songs plots about the death of a Cossack.

Our analysis shows that the directions of reflection in folk songs of the problem of separation from Ukraine in the scientific literature are not studied explicitly.

\section{AIM OF THE ARTICLE}

The main aim of this study is the systematization of verbal manifestations concerning pining for the native land as they are reflected in Ukrainian folk art. We also focus on the ways that folk art introduces to prevent loss of self-identification.

\section{METHODOLOGY}

The obtained work results are based on the analysis and systematization of the literary sources and archives data, which contain samples of literary creativity, in the context of revealing the attitude of the narrator to the native land under different life circumstances. Historical examples of consolidating the principles of Ukrainian selfidentification in the human worldview are taken into account.

A number of situations have been singled in which personal attitude to the native land is keenly felt: work or military operations abroad; colonization of lands, migration in search of a better fate, betrayal; captivity or captivity that ended in assimilation; evacuation or emigration to avoid areas of hostilities, repression, etc. There is another type of separation from the native land - the forced loss of the native language in their homeland, for example, the gradual Russification of the population in Ukraine, which was observed during both Russian tsarism and Soviet rule. Ukrainian cultural identity is revealed through a number of real-life situations 
reinvented in folk art. Being emotional, a person tends to show a plethora of various emotions in the song. Therefore, the folk song is the first source in finding out the means of self-identification.

We have not found explicit explanations or scientific analysis of the causes stimulating the narrator's nostalgia for his/ her native land. Therefore, in this work, we center on the above-mentioned problems and systematize the results achieved by other scholars in the related fields of study, such as studies of mentality. The systematization of manifestations representing pining for the native land as they are found in folk art is carried out.

\section{RESULTS}

The starting points for this study were records of the Ukrainian folk songs, found in the archive of the little-known Kharkiv poet, H.R. Ilyashenko (1911-1992). Three recorded songs were analyzed. Each one can be considered as the implementation of the topic "pining for Ukraine" (Trehubov et al., 2018). H.R. Ilyashenko was originally from Myrhorod, born into a large family. Among his descendants there were Zaporozhian Cossacks and Chumaks; the family was badly affected by typhus and the Holodomor; he sang in the church choir; as a child, he spoke only Ukrainian.

The text of the first song of the manuscript partially coincides with the text of the song "There is a sycamore tree above the water". This song tells about a Cossack who joined military service outside Ukraine, “... and died there”. In this version, there are no initial stanzas, which are in versions "a" and "b" (Shevchenko, 1995; Maksimovich, 1834), instead, there is another beginning. Below the key differences of the text are written in italics, and the traditional version is indicated in parentheses. Of the known versions of the text, the older version " $b$ " has greater similarity with this manuscript (Maksimovich, 1834): “... went abroad somewhere / The Cossack is young... / Somewhere he left Ukraine, / And there he died, / He left forever / His native country (Ukraine). / He told himself to fill (He commanded) / The high tomb, / He said to plant (He ordered) / A guelder rose near the head (the red guelder rose (Ishchuk, 2005)). / The birds will arrive, / And eat guelder rose, .../ bring / news from Ukraine". This manuscript, as well as version " $b$ ", is characterized by expressions in the perfect tense, which looks closer to the original meaning of the song and more emphasizes the tragedy that occurred, and the narrator's sadness for his native Ukraine. And the famous symbol of Ukraine "guelder rose" is used as a sign 
of connection with the native land.

The mood of the song "There is a sycamore tree above the water" contains common motives with the "Testament" by T.H. Shevchenko: "When I die, bury me in dear Ukraine. So that it was visible and could hear the wide fields, and the Dnieper, and the cliffs...". As a sign of unity with Ukraine, Shevchenko used "wide fields", "the Dnipro". Even death is not so terrible and there will be peace in the soul, says the lyrics of the song "There is a sycamore tree above the water" if "there will be news from Ukraine".

The next song in the manuscript has "genetic" connections (Trehubov et al., 2018) with the song "Oh, the fire is burning on the mountain". She tells of the death of a Cossack in battle. In the manuscript, in contrast to version "a" (Shevchenko, 1995), the first stanzas and the last stanza are missing. But the last stanza coincides with the version of the song "Oh on the Mountain at the Grave" (Ishchuk, 2005). In the Vinnytsia region, a version of this song was recorded in the form of "Oh, three summers, three Sundays" (Holubenko, 2000) with a similar plot. But this option has a different text. Only the last stanza coincides with the manuscript: "Mom, take a handful of sand and sow on the stones. When this sand (...) rises (like rye), then your son will come from the army".

The song states with sadness that the fate of the mother of a Cossack-defender of the native land is to wait for the time when the sand will germinate like rye on the fireplace. The main version of the plot in the form of the song "Oh, the fire is burning on the mountain" says that the Cossack managed to light a signal fire. Therefore, we should be proud of his actions. The connecting link with the native house is a horse, which on behalf of the Cossack brings the news home with the words: "... do not cry, mother...". The symbol of the Cossack's return home in the traditional version of the song is used "rye", which germinated magically after sowing sand. That is, death for the native land is not in vain.

The last song in the manuscript in the first stanzas coincides with the folklore text "The falcon and the blue-winged eagle became friends" (Hordiychuk, 1991), where the falcon "went" to another land to seek happiness. But the manuscript contains a significantly differentending. According to well-known sources, this part of the text tells about the hard life of abandoned children (in someversions it is said that they remained in Ukraine). At this time, the "falcon" in a foreign land is thinking: to linger or return. And returning three years later, it curses misfortune, when he finds no property or 
children. But according to the new version found, the falcon asks the eagle to teach its children not to look for happiness in a foreign land: "I will go to / A foreign land / To seek happiness. / Oh, if all goes well, / Then maybe I'll be late. / But if I feel bad, / I may not return (Then I will return). / Teach my children / To fly high. / Teach them / In a foreign land / Not to seek happiness". This ending changes the meaning of the song and is consistent with the image of the "blue-winged eagle" that was used. Because blue symbolizes the sky and a dream. These lines, the analogues of which are not found in the literature, are relevant today.

It should also be noted that the known versions of the song do not make it clear the intention to use the images of a falcon and an eagle to teach the plot in the form of a song and a poetic fable. Zoomorphic images in songs are more often used to reinforce the main plot, which relates to the actions of certain people. Based on the traditional symbolism of Cossack songs, the images of "eagle" and "falcon" are used to allegorically replace the images of a Cossack or a Kosh ataman. The image of the "eagle" sometimes symbolizes the Cossack army. The origins of ornithological symbols stem from mythological notions about the possibility of turning people into birds, so they are used as a source of knowledge about the world around them (Mykytiv, 2008).

According to the given variant, the falcon turns to the eagle as a source of knowledge. Since the eagle did not seek happiness in a foreign land (ie remained in Ukraine), he had some knowledge on this issue. Therefore, there is a request to the eagle to pass this knowledge to the children of the falcon, because the eagle flies higher than the falcon and sees, that is, knows in advance that in a foreign land there will be no happiness. And since the eagle can symbolize the Cossack army, we can assume that the falcon served another side. Then, from many versions of this song, it follows that in this case there will be no happiness for the falcon, or his children, or his native land. The presence of metaphors, zoomorphism, and the use of images of animals together with instructive content makes this song one of the oldest poetic fables in Ukraine.

In the above folk songs, as well as in the will of T.H. Shevchenko, there is a request for unity with the native land - Ukraine. Love for Ukraine in them is combined with the sadness of separation from her, as in the lines of H.R. Ilyashenko (Trehubov et al., 2018): “... Dear birches, willows, poplars, / trees of life and beauty, / although there are many troubles in the world, / the times of light will come". That is, the peaceful life of Ukraine needs protection from "misfortune" and then "light times" will come. Another interpretation can be assumed: since the author of these lines 
lived in a Russian-speaking environment, he missed his native Ukrainian language. Then "light times" are the hope for the return of the Ukrainian-speaking environment to its historic land. Thus, separation from the native Ukrainian language is equivalent to separation from Ukraine.

Analyzing the above Cossack songs, we see that they are not ritual songs, but closer to kobzar songs, and therefore these pieces are most often performed by one performer.

Dumas were higher art for kobzars, followed by historical, Cossack and Chumak songs. But there is a typological similarity between them, which consists of the realization of the need to express depressing feelings and the creation of a certain mental concentration, which leads to catharsis (Kolessa, 1921). Historical songs tell about the lives of famous historical figures, Cossack - about the life of the Cossacks in general. It is suggested that the origin of kobzar heroic songs dates back to older times than is commonly believed (Lozko, 2011). This definition fits the poem "The Word about Ihor's Regiment”, which can be considered the first Ukrainian heroic People's Duma (Dmytrenko, 2009). Boyan sings this Duma in a sad voice: “... The ground under the hooves is sown with bones, drenched in blood,... O wind, sail! Why, my lord, do you blow by force? Why do you throw enemy arrows... Against the soldiers of my beloved? ..." (Rylsky, 1986).

"The Word..." uses the image of water as a symbol of separation. For example, the word "Danube" had two meanings: the name of the river and the designation of the spring flood "danube". Accordingly, in different parts of the text, the above word had to be written starting with lowercase or uppercase letters. But the original text of the manuscript has not survived. Analysis of the meaning of sentences shows that in later times of rewriting the text, the past meaning of the word "danube", as now, was lost. Therefore, an unknown scribe corrected the "errors" and wrote the word, starting with a capital letter. The author of "The Word..." also uses the term [ozero] (lake) to describe the large perimeter of the spilt river, [more] (sea) to denote deadly water. This opinion eliminates a number of misunderstandings in the interpretation of the text. For example, a phrase like "Girls sing on the Danube. / Voices are heard across the sea to Kyiv" researchers understand as a hint at the works of that time, which describe the campaigns of Svyatoslav. In our opinion, this phrase has a different meaning: the girls sing by the river, their singing can be heard through the "big water" in Kyiv. Indeed, the events of "The Word..." unfold in the 
spring. "Yaroslavna's Cry" also has a misunderstanding: Yaroslavna went to the Danube but appealed to the Dnieper. Therefore, the phrase "On the Danube, Yaroslavna's voice can be heard..." should be understood as "Yaroslavna's voice can be heard above the spill". That is, water was an environment that had the ability to separate people.

At the same time, "The Word..." uses the image of a combination - it is Yaroslavna, who turned into a "zygzycia" and flew to save her lover. The origins of this image go back to pagan sorcery; researchers have not defined what is a "zygzycia" - a cuckoo, seagull, or other bird. The following motives, as noted, are found in folk songs: the wife (mother, sister) flies to the Cossack who died or goes to the army, or she flies to the chumak (son, recruit) turning into a swallow ("Oh, the fire is burning on the mountain") or, more often, into a cuckoo ("Oh, the falcon flew", "Hey, little widow", "Well in the field”) (Kuzmenko, 2013), also - "Cuckoo forged early", "Flying cuckoo", "In the field is birch" (Hordiychuk, 1991). In this case, the cuckoo is a message, a reproach, a sign of unhappiness, and separation from something native: "Mother was standing, Hey, she was preparing her son for the road”, "Oh, she was waiting... I had sent a gray cuckoo", "I didn't hear the cuckoo... she didn't hear my voice", "The cuckoo forged... She told the whole truth", "Tell me, cuckoo... My beloved husband far away...", "I became a cuckoo, I flew to my mother to make her feel sorry for me”, “... cuckoo forges... Where is my beloved husband...?”, and others (Hordiychuk, 1991), ... cuckoo forged, she reminded mother about her son", "it was not a cuckoo that forged, it was a sister (widow), she wrote letters from another land", "I ask you, gray cuckoo, to pass the news about me to my mother" (Kolesca, 1921). If we take into account that based on the number of forging cuckoos there is a long tradition of counting the years left for life, we tend to think that Yaroslavna has become a cuckoo that is a symbol of the separation bitterness.

"Yaroslavna's Cry" can be seen as the reverse side of separation from Ukraine, as a generalized longing by a mother, sister, wife or daughter for a soldier who left his native land during a military campaign.

A similar mood is expressed by M. Haivoronsky in the song "A Cossack went to war" (Stadnyk, 2008). As part of this plot a soldier says goodbye to his beloved bride-to-be, and in order to communicate with her asks to give him a handkerchief. In the worst case, this handkerchief will remain an inseparable link with the family in a grave: "Give me a handkerchief, girl. Maybe I'll die in battle. The handkerchief will cover my eyes during the dark night, It will be easier to rest in the grave!”. 
Issues of separation from Ukraine are also considered in the People's Dumas. Thus, "Marusya Boguslavka" (Pavliy, 1955), having been taken prisoner and into the harem of the sultan, took the opportunity to release Ukrainian prisoners from the prison, but she herself remained, as fate turned her into a Turk. But, as in the song "Oh, the fire is burning on the mountain", Marusya Boguslavka's only pain is the lack of connection with her family and parents, so she wants the news about her to reach home, and appeals to the Cossacks: “... Just don't miss the city of Bohuslav... But let my father not will redeem me, Boguslavka, from captivity. Because I have already become a Turk and a Busurman for the Turkish luxury, for unfortunate sweets!" Almost with these words "Duma on Samiyla Kishka" (Дума про Самійла Кішку) (Pavliy, 1955) describes the "Lyakh Buturlak, a locksmith of Galer, who was thirty years in captivity, became a Turk and became a busurman for the great nobility, for the unfortunate sweets!" The Cossack ataman found a way to persuade Lyakh to flee. The only thing that still brings Lyakh closer to his home is the Christian faith in his heart.

The song "Cossacks passed" tells about the deportation of a girl from Ukraine (Petrukhina, 2007). But it becomes unclear and the girl's consent to go with a group of unfamiliar men, and the ill-treatment of a group of Cossacks with this girl. Then the girl begs other Cossacks for salvation, but some options do not describe their reaction to such treatment, and the other part - shows restraint. At once, it is possible to note that to suffer insults from some Cossacks, and then to beg for rescue in others seems illogical. In the Soviet interpretation, this song is sung cheerfully, which, given its content, is also incomprehensible. None noble behavior of the Cossacks does not allow us to attribute this plot to the heroic Ukrainian epic. We can assume that this song was performed for a long time in the form of the People's Duma.

We believe that the names "Cossacks passed" or "Galya-bartender" are bad for this song, and the best name in terms of meaning is "Duma about Galya and the Cossacks". It should also be noted that the name "Galya" is typical, common, and in the Poltava region - as a generalized name of a girl; "bartender" is a generalized kind of occupation which explains a possibility of casual acquaintance in the village with men (as well as at a well). According to different variants, the Cossacks, the Wallachians, the Khazars, the Tatars, the Turks, the Liakhs, the Muscovites, the Prussians, the Poles, the Don Cossacks, and the Tulaks visited the tavern. Thus, given the generalized, allegorical, symbolic, and instructive nature of the plot elements, 
this duma, as well as "The falcon and eagle became friends" can be considered a fable as a short work of instructive content (people are rarely characters in fables when their images appear symbols of certain human traits).

The analysis shows that this song has undergone significant changes during its existence in people's memory. The presence of archaic allusions to ancient wedding ceremonies allows us to attribute the emergence of the plot to the time of the preChristian Slavs. For example, to explain the fact that the girl went to travel with several men is possible if we mention the polyandry in Drevlyany or the tradition of "men's house", where the girl for some time played the role of a wife (Petrukhina, 2007). There is also a coincidence of this plot with the myth of the Rain Cloud and Thunder, the origins of which are attributed to Indian mythology (Nechuy-Levytsky, 1992).

On the other hand, the song mentions ancient ritual actions. The song describes the incomprehensible actions of burning a girl under a pine tree. However, there is an analogy with marriage traditions, when the bride is standing under a burning tree: "The pine tree was burning - the girl was standing" (Petrukhina, 2007). This pre-marriage rite becomes a ritual purification with the help of fire, which helps to symbolically turn a girl into a woman. (just as the white color of a wedding dress is a farewell dress for a girl in a ritual burial ceremony to start a new life regardless of the past). At some intermediate stage of rethinking the original archaic plot, the meaning of the song acquired the following meaning: the girl married in a foreign land, but other people's traditions proved unbearable for her, and she begged for salvation, which is found in many Ukrainian folk songs. Then (according to some versions of the song) the inaction of the Cossacks in response to the request for salvation is understandable because the girl is already legally married.

The summary of the song can be summarized as follows: foreigners (not the Cossacks) persuaded the girl to go with them in the status of a polyandry marriage from the native land to a distant foreign land and promised good living conditions, but the girl did not find happiness abroad, so there is an instructive request to those "who have daughters - let him teach" (the girl asked random Cossacks to save her, but they decided not to interfere in other people's traditions).

Thus, the content of this song eventually overlapped with new problems and loss of understanding of the old content of the text. However, this plot raises the topic of captivity and the possibility of liberation from it, or another type of separation from Ukraine - voluntary departure for marriage abroad. In addition, the girl's only hope 
Trehubov Dmytro, Trel

for salvation rests on the Cossack as a link with his native land.

Ivan Franko considers the search for a better destiny abroad in the cycle of poems "To Brazil", which was included in the collection "My Emerald". The cycle is based on real events: an agent dressed as a simple man walked through Galicia, inadvertently was saying that life was better in Brazil. Many Ukrainians reacted to the promise of a better fate, but the truth of Brazilian life at that time turned out to be cruel. I. Franko described the condition of a migrant Ukrainian in the following words: “... He remembered his native country with tears, But with a curse, he ran away from her" (Franco, 1976). In this case, the emotional conflict of separation from the native country is shown when it is impossible to stay in its territory.

O. Storozhenko in the story "The Devil in Love" reveals the emotional state of a person in case of return to his native land - Ukraine and, at the same time, shows the approximation of "Moscow traditions" to the lands near Kharkiv at the time of the mid-nineteenth century (Storozhenko, 1990): “... When you go from Kursk province to Kharkiv... I was lucky to be in my native Ukraine sometimes, but how long will you rest under her warm wing?... it will be light as if you were lifted on the wings!... But from the village of Liptsi ( $20 \mathrm{~km}$ from modern Kharkiv to the north: the author's note) our Ukraine looks like Muscovy now - instead of taverns cursed squash, inns in the Moscow custom; ...but when you cross the river Kharkiv (in the village of Liptsi, author's note), who would not say that this is God's side!... It seems that our native Ukraine has come out to meet you... it sings a song...”. That is, Kharkiv was at that time a city of Ukrainian culture. O. Storozhenko notes the most expensive features of native Ukraine for the Ukrainian: "Covers you with a warm wing" so that you allegedly fly on wings, because this "land of God" greets you with a "song", that is, a native language. Perhaps love for the native language is the most reliable sign of self-identification. This story reveals the nostalgia that arose as a result of separation from Ukraine, the joy of returning to Ukrainian lands (to Kharkiv), and testifies to the fascination of these lands with Russian traditions. Native Ukrainian land has now become alien to the author. That is, you can feel separation from Ukraine within Ukraine. The expansion of foreign culture creates a similar effect on the spiritual state of man. It was in the case of the previously mentioned H. Ilyashenko, who found an outlet among the Russian-speaking environment only in poetic work in the Ukrainian language. 


\section{DISCUSSION}

Regarding the expansion of Russian culture, it can be noted that according to the 1897 census, the Kharkiv region was characterized by the wide spread of the Ukrainian language - 80\% (Language Composition, 2019). The least Ukrainian-speaking city in the Kharkiv region was Chuguiv. It was founded in the seventeenth century by the Cossacks. But after that, it received many artificial waves of resettlement. Thus, in the seventeenth century, about 2,000 archers and Kalmyks were relocated to the city of Chuguiv. Therefore, the inhabitants of the city have long been called "gathered", those who came from different places. During the industrial revolution in tsarist Russia and the "mixing" of the population under Soviet rule, the Kharkiv region has lost the Ukrainian language as the main language of communication. But the important thing is that people who live and work in the villages of the region keep talking Ukrainianspeaking Surzhik, even on the border with Russia.

The expansion of Russian culture was a by-product of the artificial resettlement of Russian-speaking people to Ukrainian lands. First, there was the "conquest by friendship" - an imitation of a mutually beneficial relationship. Then the authorities introduced new traditions and orders. That is, there was an artificial absorption of the indigenous population by newcomers. During the takeover of Ukrainian lands by Russia, such actions were repeated many times. Recent examples include the aftermath of the Holodomor, the deportation of Western Ukrainians and Tatars from Crimea after World War II (Bugay, 1990), and the seizure of Crimea in 2014. If we compare with the epochs of the spread of Tatar, Lithuanian and Polish power to the Ukrainian lands, we can see that the Golden Horde required only obedience without interfering in culture and religion; The Grand Duchy of Lithuania followed a similar policy. Ukrainian culture underwent a severe expansion during the rule of the Polish-Lithuanian Commonwealth after the Lublin Union in the form of planting the principles of social, religious, and national spheres (Palamarchuk, 2015). However, the policy of deportation and replacement of the population was not implemented. Therefore, it can be argued that eastern Ukraine has been under pressure from overrigid expansion for more than 300 years, which is at the same time disguised.

The result of the principles of Russian expansion is a violation of the chain of transmission of culture and the creation of conditions for "forgetting" the native language by the indigenous population. This can be either a conscious policy of the Russian Empire or an intuitive action, but it is enshrined in its international policy 
and is still used as a method of conquering the world. And it turns out that with the development of information technology, the effectiveness of such actions is facilitated.

How do people forget their native language? How does a person who has stopped speaking his native language during his life feel? Many people in this situation do not find a way to preserve the language. They forget who they are, even though they do not cross the borders of Ukraine. According to Mykola Voronyi, who poetically embodied the Polovtsian legend, there is a magic herb "evshan-potion", which helps to restore forgotten roots in memory (Voronyi, 2010). Even if a person has several roots, there is a continuous chain of human connection with folk traditions through past generations. Perhaps the most important of these is the one closest to the ground. It is by breaking away from the earth that people lose their ancestral memory. There is no man without roots, and if she has forgotten them, she needs that magic grass. Kalinets I. (2012) in the almanac "Evshan-Zillya" summarized that a Ukrainian if he lost his native land in his soul, needs: “... for those who are indifferent in spirit... need bitter wormwood..., the bitterness of life brings a person... back to the beginning...”.

M. Tkach a recognized Ukrainian cultural figure, managed to remain in the Ukrainian creative environment even in Soviet times. He was born in Transcarpathia under Romanian rule and the holiday was the return of these lands to the Ukrainian mental space in 1940. Apparently, since then, the nostalgia for the loss of his native land, which sounds in the song "My Ukraine", has remained in the heart of M. Tkach (2002). He cannot imagine himself without Ukraine, from the window of which "fate shines". In the song, the author imagines himself next to the "blonde hut", which is the image of Ukraine: "I hear your voice, her ear of wheat sows grain in my soul. My Ukraine, guelder rose, fate has given me the happiness to know you. Without you, I have sorrow like a crane without a nest in a foreign land. My Ukraine, White-washed "blonde-hut", Fate shines for me from your window". The author has found many famous and personal images that unite him with his native land and do not allow him to lose self-identification. It is noteworthy that every time fate tore the author away from his native Ukraine, he felt sad: “...the sadness of a crane without a nest in a foreign land". But, at the same time, he saw with his heart the light that allowed him not to get lost in the ways of life. Still, M. Tkach had his own "evshan-potion".

The relay race of searching for elements that contribute to the self-identification of Ukrainians was well-supported by Tina Karol's modern song "Ukraine is you", which was included in the school curriculum of junior classes in 2016 (Zinchenko, 2020). 
Astraea, V0102, $\mathbf{1} 01,1,2021$

On the one hand, in comparison with M. Tkach's song, which reflects the pining for the motherland, the song "Ukraine is you" provides an unsystematic set of images familiar to the Ukrainians. On the other hand, if you analyze this work, you can feel the strife for "evshan-potion", close to every Ukrainian heart. For example, the song compares Ukraine to a family that creates a chain that stretches back centuries to the roots of Ukrainianness. The words that the father has said to the children, that is, the conscious beliefs, and the "mother's songs" that appeal to the subconscious help to reach these roots. The image of the native land is created with the help of a composite picture, which consists of individual elements of a song, like a mosaic: "Storks wing" over the roof of the house is a talisman of family happiness, "Embroidered shirt" is one of the most important attributes that has been passed down between generations, the picture is complemented by the "sun" and "blue sky" that are present above that house, and next is the "fog over the gray Dnieper" and "wide steppe", which together create the image of "freedom" of the Ukrainian. "Sunflower" is used in a generalized image of Ukrainian happiness. This sequence of images describes the state of the Ukrainian, when "God is with us" is a state of happiness and a state of "hope", which is embodied in "love" and "dreams" when there is no need to look for the best. And a person who has heard such a song returns to his roots, with a conscious attitude to his own self-identification.

Any self-identification is impossible to imagine without love for the native land. According to Seneca, the homeland is loved not because it is big or small, but only because it is its one 's own. It is the one in the heart. Therefore, self-identification is vivid in folk art and deeply reflects the pining for his native land.

\section{CONCLUSION}

The loss of a person's self-identification begins with the loss of his/her desire to communicate using his/her native language. In folk songs the loss of the native language is compared to death. Manifestations of Ukrainian self-identification in songs are more often observed in the emotional state of pining for Ukraine. It can happen under different circumstances: working abroad, death in battle, recruitment into the army, leaving the country in an attempt to find a better place for living, captivity, betrayal of the homeland, emigration on the occasion of marriage, finding the territories of the country under occupation, etc. If a person has lost self-identification and connection with the roots, then he/she needs the so-called "evshan-potion" - a 
certain symbol, rite of purification, which will help to understand the forgotten. There are the following relevant elements in Ukrainian songs and dumas: evshan-potion, a song, a guelder rose, the Dnieper, fields, a horse, a handkerchief, a white hut, rye, a swallow, wheat ear, Christian faith, "father's words", "mother's songs", a stork, an embroidered shirt, a wide steppe, "faith that God is with us" and others.

Funding: This study received no specific financial support.

Competing Interests: The author declares that there are no conflicts of interests regarding the publication of this paper.

\section{References}

Bondarenko, O. V. (2008). Ukrayins'ka mental'nist' v rozmayitti natsional'nykh mental'nykh formoutvoren' y arkhetypiv: istorykokul'turnyy aspekt [Ukrainian mentality in the diversity of national mental formations and archetypes: historical and cultural aspect]. Humanitarnyy visnyk ZDIA, 32, 66-78 (in Ukrainian).

Buhay, M. F. (1990). Deportatsiyi naselennya Ukrayiny (30-50-i roky) [Deportations of the population of Ukraine (30-50s)]. Ukrayins'kyy istorychnyy zhurnal, 11, 20-33 (in Ukrainian).

Dmytrenko,M.(2009). Ukrayins'ki narodni istorychnipisniyakob'yekt doslidzhennya [Ukrainian folk historical sights as an object of research]. Narodoznavchi zoshyty, 1-2, 2009, 135-146 (in Ukrainian).

Holubenko, I. O. (Red.) (2000). Vidlunnya lisu [Echoes of the forest]. Kyyiv: IHS (in Ukrainian).

Hordiychuk, M. (Red.) (1991). Perlyny ukrayins'koyi narodnoyi pisni [Pearls of Ukrainian folk song]. Kyyiv: Muzychna Ukrayina (in Ukrainian).

Ishchuk, M. (2005). Vasyl' Stus i ukrayins'ka narodna tvorchist' [Vasyl Stus and Ukrainian folk art]. Narodna tvorchist' ta etnohrafiya, 1, 85-89 (in Ukrainian).

Franko, I. YA. (1976). Zibrannya tvoriv. T. 2 [Collected Works, Vol. 2]. Kyyiv: Naukova dumka (in Ukrainian).

Kalynets', I. (2012). Shlyub iz polynom: poeziya [Marriage with a wormwood: poetry]. L'viv: Spolom (in Ukrainian).

Kolesca, F. M. (1921). Pro genezu ukrayins'kykh narodnykh dum [On the genesis of Ukrainian people's dumas]. L'viv (in Ukrainian).

Kuz'menko, O. (2013). Sotsial'no-pobutovi pisni v doslidnyts'kiy praktytsi Filareta Kolessy [Social-household songs in the unitary and research practice of F. Kolessa]. Rodyna Kolessiv - spadkoyemnist' naukovo-mystets'kykh tradytsiy, L'viv, LNU, 111-164 (in Ukrainian).

Lozko, H. S. (2011). Ukrayins'ke narodoznavstvo [Ukrainian ethnology]. Ternopil': Mandrivets' (in Ukrainian).

Maksymovych, M. (Red.) (1834). Ukraynskiya narodnyya pesny [Ukrainian folk songs]. Moskva: Unyversytet. (in Russian). 
Mykytiv, H. V. (2008). Khudozhn'o-obrazna paradyhma symvoliv v ukrayins'kykh kozats'kykh pisnyakh [Artistic and figurative paradigm of symbols in Ukrainian Cossack songs]. Visnyk ZNU. Filolohichni nauky, 2, 146-152 (in Ukrainian).

Movnyy sklad naselennya povitiv Rosiys'koyi imperiyi za perepysom 1897 roku (2020, traven' 17) [Linguistic composition of the population of the Russian Empire counties according to the census of 1897]. Retrieved from https://datatowel. in.ua/pop-composition/language-counties-1897 (in Ukrainian).

Nechuy-Levyts'kyy, I. (1992). Svitohlyad ukrayins'koho narodu. Eskiz ukrayins'koyi mifolohii [Worldview of the Ukrainian people. Sketch of Ukrainian mythology] K.: Oberehy (in Ukrainian).

Palamarchuk, N. F. \& Ihnatova, L. R. (2015) Lytovs'ko-pol's'kyy period v ukrayins'kiy istoriyi derzhavotvorennya [Lithuanian-Polish period in the Ukrainian history of state formation]. Storinky Istoriyi, 10, 12-21 (in Ukrainian).

Pavliy, P. D. (Red.) (1955). Ukrayins'ki narodni dumy ta istorychni pisni [Ukrainian folk dumas and historical songs]. Kyyiv: AN URSR (in Ukrainian).

Petrukhina, L. (2007). "Bidna Halya" u tenetakh kolektyvnoho shlyubu ["Poor Galya" in the networks of collective marriage]. Visnyk L'vivs'koho universytetu. Seriya filolohichna, 41, 266-275 (in Ukrainian).

Pidhorna, L. (2013). Tvorchist' Mykoly Kostomarova yak vyyav natsional'noyi samobutnosti u dobu romantyzmu [Mykola Kostomarov's work as a manifestation of national identity in the era of romanticism]. Ukrayinoznavchyy al'manakh, 11, 273-276 (in Ukrainian).

Popovych, M. V., Kyslyakovs'ka, I. V., Vyatkina, N. B, Navrots'kyy, V. V., Vasyl'chenko, A. A., Kokhan, YA. O. ... Yolon, P. F. (2006). Problemy teoriyi mental'nosti [Problems of the theory of mentality]. Kyyiv: NAN Ukrayiny (in Ukrainian).

Ryl's'kyy, M. (Per.) (1986). Slovo o polku Ihorevim [The word about Igor's regiment]. Kyyiv: Radyans'ka shkola (in Ukrainian).

Shevchenko, M. V. (Red.) (1995). Naykrashchi pisni Ukrayiny [The best songs of Ukraine]. Kyyiv: Demokr. Ukrayina (in Ukrainian).

Stadnyk, O. (Red.) (2008). Spivaye Volyns'kyy narodnyy khor. Pisenni skarby krayu [Volyn folk choir sings. Song treasures of the region]. Luts'k: Volyns'ka oblasna drukarnya (in Ukrainian).

Storozhenko, O. (1990). Zakokhanyy chort [Loving devil]. Ohnennyy zmiy. Fantastychni tvory ukrayins'kykh pys'mennykiv XIX st. Kyyiv: Molod', 137-154 (in Ukrainian).

Tkach, M. M. (2002). Struna: Vybrane [Loving devil]. Kyyiv: Kyyivs'ka pravda (in Ukrainian).

Tkachenko, L. (2014). Hryhoriy Skovoroda: ekzystentsiyni dominanty zhyttyetvorennya [Hryhoriy Skovoroda: existential dominants of life creation]. Ridna shkola, 11, 64-69 (in Ukrainian).

Trehubov, D. G. \& Trehubova I. M. (2018). Rozhlyad problemy rozluky kozaka z Ukrayinoyu v narodnykh pisnyakh [Consideration of the problem of separation of the Cossack with Ukraine in folk songs]. Literatura y istoriya, ZNU, 150-151 (in Ukrainian).

Voronyi, M. (2010). Yevshan-zillya [Yevshan-zill]. Kyyiv: Natsional'nyy knyzhkovyy proekt (in Ukrainian).

Zinchenko, A. I. (2020, traven’ 17). Urok “Vichno v sertsi zhyve Ukrayina” [Lesson 


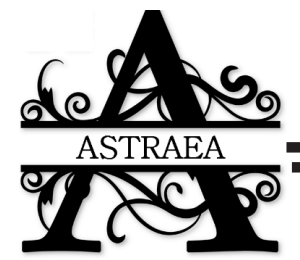

"Ukraine lives forever in the heart"]. Na urok, 2018. Retrieved from https:// naurok.com.ua/urok-vichno-v-serci-zhive-ukra-na-27671.html (in Ukrainian).

Received: 21.11 .2020

Accepted: 15.05.2021

\section{Cite this article as:}

Trehubov, D., Trehubova, I.(2021). Self-identification of the Ukrainians through pining for their native land (on the material of folk art). Astraea, 2(1), 96-114. doi: 10.34142/astraea.2021.2.1.06

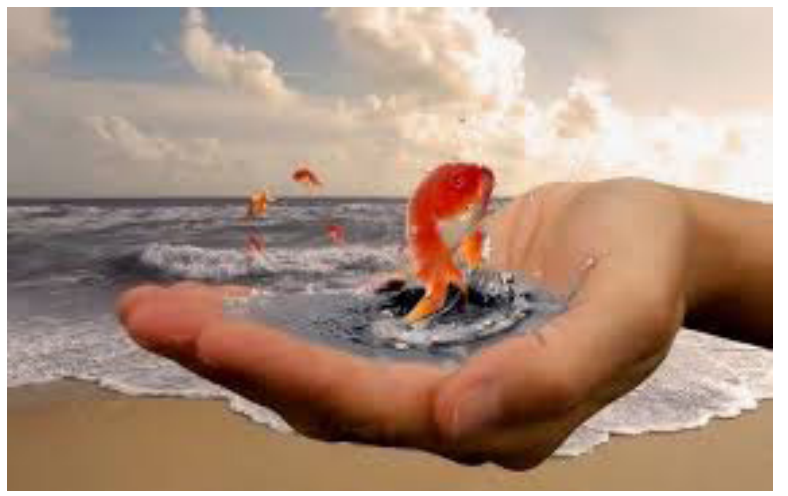

